\title{
Monitoring and Modelling Interactions between the Montagna dei Fiori Aquifer and the Castellano Stream (Central Apennines, Italy)
}

\author{
Alberto Tazioli ${ }^{1}{ }^{\circledR}$, Nicolò Colombani ${ }^{1}{ }^{\circledR}$, Stefano Palpacelli ${ }^{1}$, Micòl Mastrocicco ${ }^{2, *}$ and \\ Torquato Nanni ${ }^{1}$ \\ 1 SIMAU—Department of Materials, Environmental Sciences and Urban Planning, Università Politecnica \\ delle Marche, Via Brecce Bianche 12, 60131 Ancona, Italy; a.tazioli@univpm.it (A.T.); \\ n.colombani@univpm.it (N.C.); s.palpacelli@univpm.it (S.P.); t.nanni@univpm.it (T.N.) \\ 2 DiSTABiF-Department of Environmental, Biological and Pharmaceutical Sciences and Technologies, \\ Campania University “Luigi Vanvitelli”, Via Vivaldi 43, 81100 Caserta, Italy \\ * Correspondence: micol.mastrocicco@unicampania.it; Tel.: +39-0823-274609
}

Received: 31 January 2020; Accepted: 27 March 2020; Published: 30 March 2020

\begin{abstract}
Groundwater is the most used water resource around the world, but due to population growth and climate change the alluvial lowland aquifers are often polluted and over-exploited. Thus, more and more frequently water managers need to shift their attention to mountain regions to identify groundwater resources for drinking purposes. This study presents a monitoring and modelling approach that allowed to quantify the inflow from the "Montagna dei Fiori" fractured aquifer to the Castellano stream. Continuous monitoring of flow discharge and temperature during an entire hydrological year (2018-2019) at two monitoring stations along the stream allowed to discriminate between the baseflow (on average, $0.891 \mathrm{~m}^{3} / \mathrm{s}$ ) and the run-off (on average, $0.148 \mathrm{~m}^{3} / \mathrm{s}$ ) components. A hydrogeological basin-wide numerical flow model (using MODFLOW-2005) was set up using information from hydrogeological and geomechanical surveys. The model was calibrated using the daily baseflow observations made in the Castellano stream $\left(R^{2}=0.75\right)$. The calibrated model allowed to quantify groundwater/surface water interactions. After an automated sensitivity analysis (using MODFLOW-2000), the recharge was found to be the most uncertain parameter, followed by the hydraulic conductivity zonation. This methodology could be applied in other mountain regions where groundwater monitoring networks are usually lacking to improve water resources management.
\end{abstract}

Keywords: Continuous stream monitoring; fractured aquifer; model calibration; drinking water resources; integrated water resources management

\section{Introduction}

Continuous monitoring of water fluxes and temperatures in stream reaches fed by groundwater are often key points to understanding water flux exchange from groundwater/surface water interactions [1,2]. Stream flow and temperature continuous monitoring are often a key point to understand water fluxes exchanges from and to aquifers in lowland river catchments [3-5], or by using remote sensing where monitoring well networks are scarce or absent [6]. As mentioned above, in recent literature there are many examples of surface waters/groundwater exchange fluxes determined by for example streambed temperature data, piezometric head data and simple 1D models or analytical solutions for flux calculation. Nevertheless, often only small-scale and site-specific information can be gained on the relationship between streams and aquifers without employing complex three-dimensional numerical models [7]. Although numerous models have been successfully developed for use in porous aquifers $[8,9]$, their application in fractured aquifers is more problematic. Fractured media are generally 
highly heterogeneous since they are dominated by secondary porosity (along fractures apertures) and often are characterized by hierarchical permeability structures [10]. In these media, turbulent flow components may develop limiting the application of numerical simulations, since most numerical models are based on the Darcy's law, which is valid only for laminar flow conditions. To avoid such problems, the "black box" model approach has often been employed in the recent past to simulate fluxes in fractured aquifers [11]. The latter is a lumped parameter model, often referred to as surrogate model, where the spatial dimension is not accounted for. These surrogate models showed often good agreement between measured and simulated spring and/or stream discharges and they have been recently used to predict spring discharge [12]. The main advantage of such surrogate models is that data prerequisites are minimal and simulation runs are extremely fast, although no information is provided on internal fluxes and exchanges [13]. On the contrary, numerical groundwater flow models have been confirmed as indispensable tools to correctly design integrated water resources management plans in fractured aquifers [14,15]. These models can be employed to validate and refine previously conceived conceptual models, or to predict the impacts of climate change or anthropogenic activities on water resources availability. The main limitation of numerical flow models in fractured aquifers is due to the complex geometry of the fractures [16,17]. In many cases, the main assumption is that at large scales, fractured media can behave like an equivalent porous medium [18-21]. However, the assumptions of the equivalent porous medium and of laminar flow, in fractured systems characterized by preferential flow paths, are not always valid especially at small scales of investigation. Under these conditions, the discrete fractures approach is generally recommended [22], but its implementation is somehow restricted because it entails comprehensive data on the geometry development of fractured systems and their hydraulic properties. In any case, if the investigation is undertaken at the whole hydrogeological basin, as in the presented case, the equivalent porous medium approach can be still considered valid [23].

From the brief literature review above, it is clear that the choice of the model mainly depends on data availability, but also by a modelling code's assumptions and the objectives of the study [24]. This paper presents a methodological approach to quantify groundwater/surface water interactions using information from hydrogeological and geomechanical surveys, borehole logs, pumping tests and continuous monitoring of flow discharge and temperature. The main contribution of this research is the use of continuous discharge and temperature measurements to numerically quantify aquifer contribution to stream flow in a fractured system. The methodology was tested on a mountainous fractured aquifer, hosted by the Montagna dei Fiori, where the monitoring wells network is nearly absent. Nevertheless, with a surface monitoring system placed along the Castellano stream, which was suspected to drain the fractured aquifer, it has been possible to calibrate a complex numerical flow model employing the equivalent porous medium approach.

\section{Materials and Methods}

The MODFLOW-2005 numerical code [25] was used to create a numerical flow model of the whole hydrogeological basin of the "Montagna dei Fiori", which is a fractured aquifer that covers an area of about $50 \mathrm{~km}^{2}$. Pre- and post-processing were done using the graphical user interface Processing Modflow 8.0 [26]. In this aquifer the parameterization of the hydraulic conductivity (K) field was field was based on geomechanical surveys of the fracture network that were used to estimate the order of magnitude of $\mathrm{K}$ for the different hydrogeological units. Pumping tests conducted in wells located near the Castellano stream, provided detailed information on the $\mathrm{K}$ distribution in the proximity to groundwater/surface water interaction zone. Given the lack of complete information on the K field in the simulated domain, it was necessary to solve the problem with the equivalent porous media method, implicitly simulating the network of fractures that allows the groundwater flow.

Therefore, the input data required for the numerical model set up were: topography, geomechanical survey of fractures distribution, aperture and direction, hydrogeological survey, pumping tests in three wells, daily precipitation and continuous flow measurements on the stretch of the Castellano stream that 
drains the "Montagna dei Fiori" fractured aquifer. To correctly quantify the groundwater/surface water interaction at the catchment scale, the entire hydrostructure of the "Montagna dei Fiori" was considered.

The main steps of the implemented methodology to monitor and model the "Montagna dei Fiori" baseflow contribution to the investigated Castellano river reach are briefly described below.

\subsection{Hydrogeological and Geomechanical Setting of the Study Area}

To avoid the use of unknown boundary conditions near the groundwater/surface water interaction zone, the entire hydrogeological basin was studied (Figure 1). Moreover, it is always advisable to use the real hydrogeological boundaries where possible, to better characterize changes in the aquifer outflow lines due to stresses such as pumping or periods with different recharge rates [13]. The impermeable boundaries of the hydrogeological basin of the hydrostructure of the "Montagna dei Fiori" are represented by folded marls, broken by the Apennine orogenetic activity. They cover the prevalently calcareous Triassic-Eocene formations, which are permeable by cracks and fractures. In contrast, the Oligo-Miocene formations are almost impermeable and outcrop in the south and in the center of the study area. In order to better detail the hydrogeological properties in the study area, a detailed map was produced for the Casteltrosino area (Figure 2) associating the lithologies with the hydraulic properties investigated in the large scale survey, to accurately localize the compressive faults and thrusts, the pumping wells, the Castellano stream and an artificial lake formed by a hydroelectric dam.

The conceptual model consists of a confined/unconfined aquifer complex with a fractured calcareous matrix that is layered with hydrogeological units made up of finer materials (marls). This feature creates a series of semi-confined aquifers that become a single unconfined aquifer only near the tectonic window, located at the center of the ridge of the Montagna dei Fiori (Figure 1). The thickness of the non-consolidated alluvial sediments is relevant only within the artificial lake "Lago di Casette" and decreases near the rocky slopes; the bedrock of the aquifer system is given by the Burano anhydrites located on average, at $-1200 \mathrm{~m}$ ASL.

Six stations were chosen for the survey of the geomechanical data in the area, to achieve a rough estimate of the equivalent permeability through the analysis of joints, fissures, fractures and any other discontinuity found in the rocks, and to have a general overview of the cracking condition in the rocks near the anticline axis. The geomechanical data were used to obtain the Schmidt stereoplots (not shown), indicating layouts and features of the discontinuities, from which the values of the maximum hydraulic conductivity (Kmax) and the equivalent hydraulic conductivity (Keq) were derived for each hydrostratigraphic unit, applying the Snow method [27]. Kmax and Keq were particularly high (Table 1) indicating a wide opening of the fractures due to the tensional release near the outcropping zones. This influences the infiltration in the unsaturated zone, focusing the majority of the recharge near the hinge of the anticline where the cracking system is wide open, and is thus capable of transferring a high volume of infiltrated water towards the saturated part of the aquifer [28]. Here, the groundwater flow takes place in fault and fracture systems, mostly oriented in Apennine direction. A geomechanical analysis and hydrogeological survey allowed the identification of the hydrogeological boundaries: the overthrust plain to the east and the normal extensive fault $\left(160^{\circ} \mathrm{N}\right.$, western dipping) to the west. 


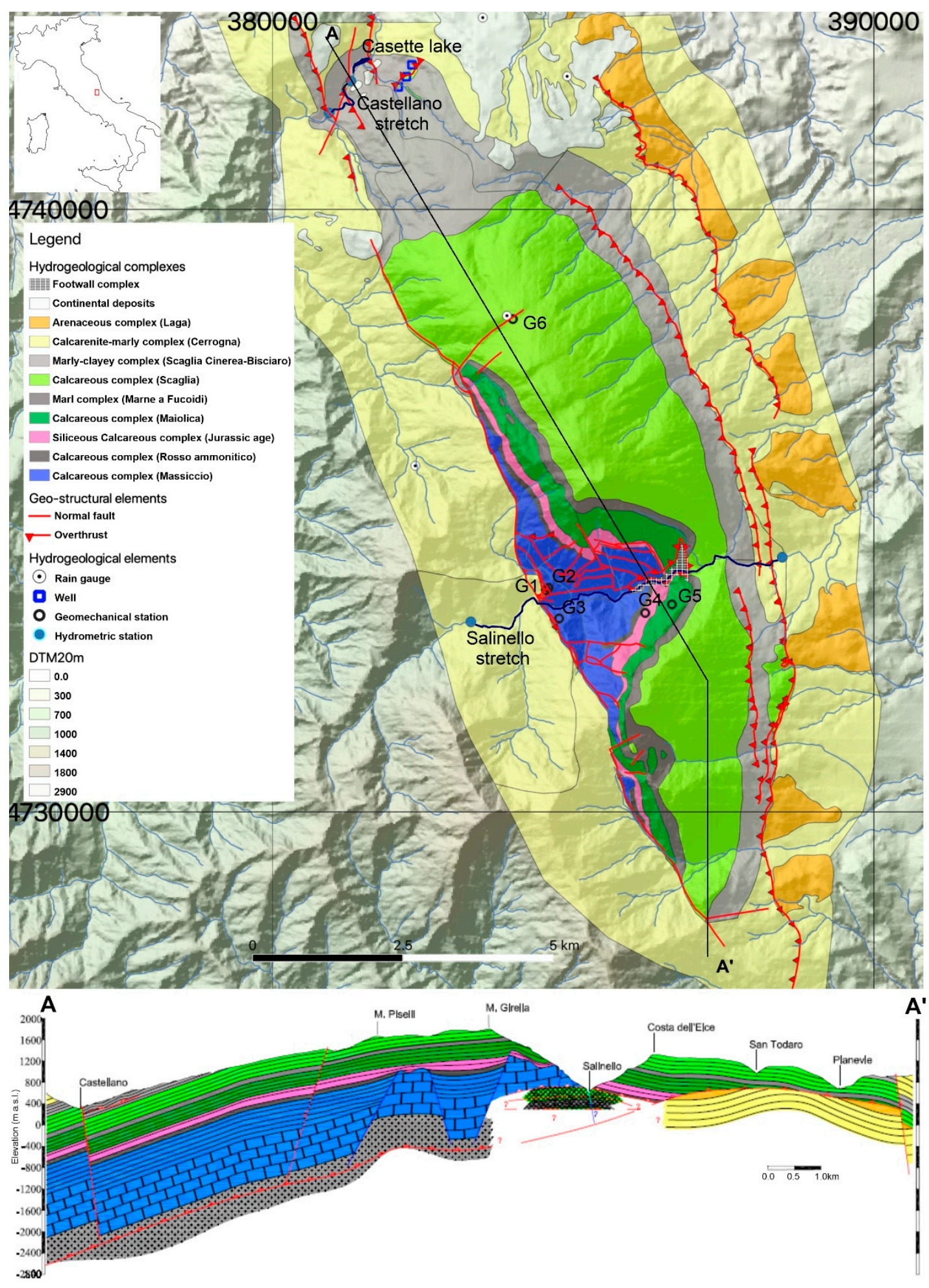

Figure 1. Hydrogeological map of the "Montagna dei Fiori" hydrostructure used to build up the numerical model domain. 


\section{Legend}

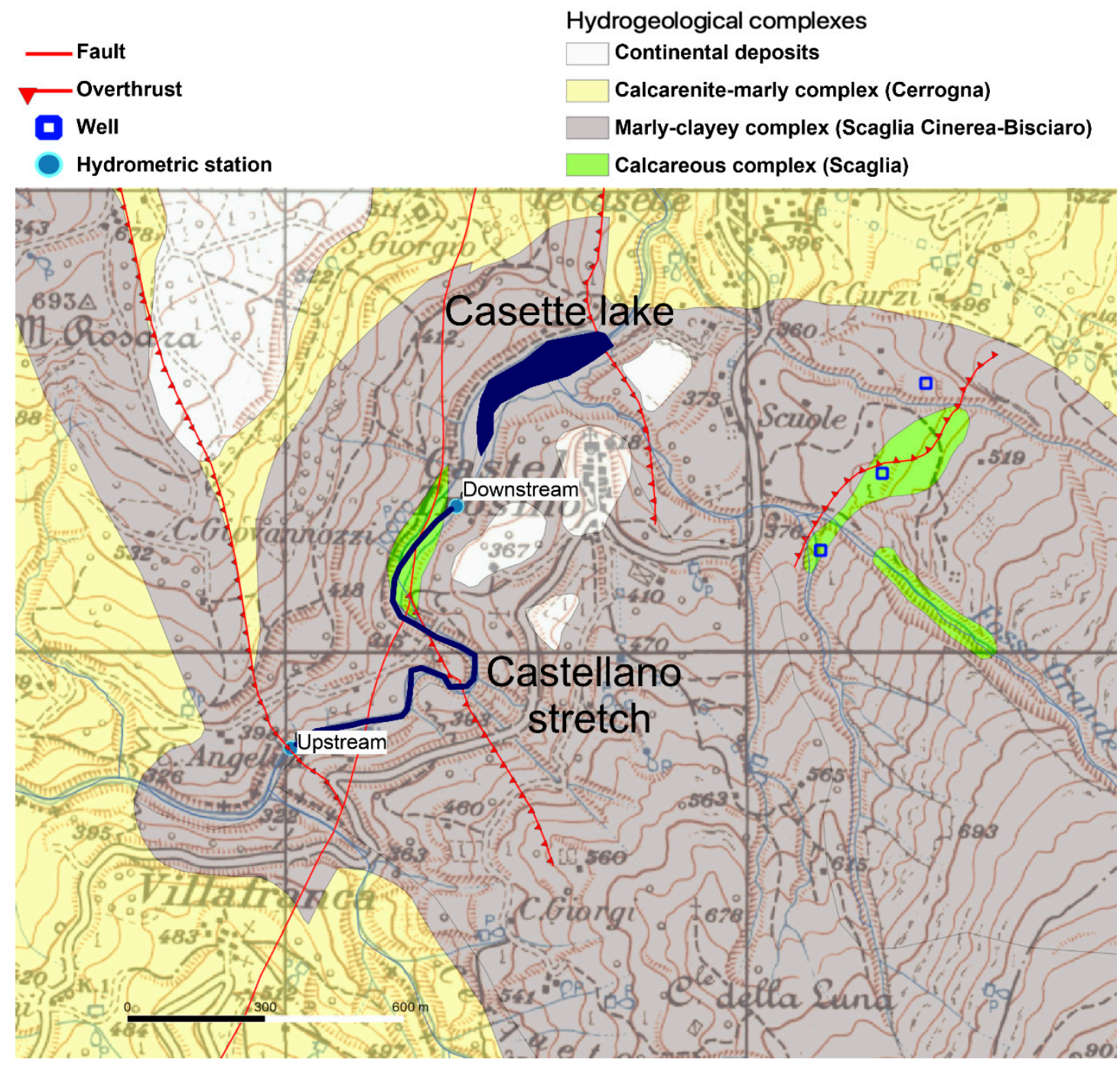

Figure 2. Hydrogeological map of the Casteltrosino area used to characterize in detail the domain of the numerical model in the area of the wells field.

Table 1. Values of Kmax and Keq derived from the geomechanical survey. The dipping plane is expressed in terms of direction and inclination of the linear element (Kmax vector).

\begin{tabular}{cccccc}
\hline $\begin{array}{c}\text { Geomechanical } \\
\text { Tation }\end{array}$ & $\begin{array}{c}\text { Hydrogeological } \\
\text { Unit }\end{array}$ & $\begin{array}{c}\text { Elevation } \\
\text { (m ASL) }\end{array}$ & $\begin{array}{c}\text { Kmax } \\
(\mathbf{m} / \mathbf{s})\end{array}$ & $\begin{array}{c}\text { Orientation and } \\
\text { Dipping Plane }\end{array}$ & $\begin{array}{c}\text { Keq } \\
(\mathbf{m} / \mathbf{s})\end{array}$ \\
\hline G1 & Calcare Massiccio & 951 & $2.0 \times 10^{-3}$ & $\mathrm{~N} 352^{\circ} / 5^{\circ}$ & $1.8 \times 10^{-3}$ \\
G2 & Calcare Massiccio & 935 & $6.5 \times 10^{-2}$ & $\mathrm{~N} 173^{\circ} / 16^{\circ}$ & $3.5 \times 10^{-2}$ \\
G3 & Calcare Massiccio & 907 & $4.5 \times 10^{-4}$ & $\mathrm{~N} 116^{\circ} / 15^{\circ}$ & $2.4 \times 10^{-4}$ \\
G4 & Jurassic Aquiclude & 868 & $9.8 \times 10^{-5}$ & $\mathrm{~N} 159^{\circ} / 4^{\circ}$ & $6.8 \times 10^{-5}$ \\
G5 & Maiolica Complex & 843 & $3.0 \times 10^{-4}$ & $\mathrm{~N} 2^{\circ} / 2^{\circ}$ & $1.8 \times 10^{-4}$ \\
G6 & Scaglia Complex & 1431 & $3.0 \times 10^{-4}$ & $\mathrm{~N} 181^{\circ} / 45^{\circ}$ & $1.5 \times 10^{-4}$ \\
\hline
\end{tabular}

Five hydrostratigraphic units were identified based on the hydrogeological survey: (i) the Scaglia calcareous complex, which outcrops in most parts of the study area, (ii) the Marne a Fucoidi marl complex, that acts as aquitard in fault zones characterized by relaxing kinematics, (iii) the Maiolica calcareous complex characterized by a good hydraulic conductivity due to fracturing, (iv) the Jurassic siliceous calcareous complex which acts as an aquiclude and (v) the Massiccio calcareous complex characterized by a high hydraulic conductivity due to fracturing. 
In this area, the recharge rate is particularly elevated since the soils are permeable, although the high terrain slope can generate elevated surface runoff. Regional literature studies put the upper limit of the recharge rate at about $600 \mathrm{~mm} / \mathrm{y}[29,30]$. No existing wells have been mapped in the "Montagna dei Fiori" basin, other than those recently implemented by the CIIP Water Company (Figure 2) drilled at mean depths of $300 \mathrm{~m}$ for drinking water supplies in case of extreme droughts. This is the only core $\log$ information available for the whole hydrogeological basin (not shown).

\subsection{Monitoring Strategy}

To obtain hydrological data on the investigated basin, a network of rain-gauge stations and hydrometric stations was installed. These data were analyzed in conjunction with the data derived from the existing monitoring network of the Civil Protection Agency of Marche Regional Authority (Figure 1).

Rain-gauge stations were positioned at different elevations along an ideal transect, from about 280 to $1430 \mathrm{~m}$ ASL. Hydrometric stations were positioned at the aquifer boundaries (upstream, where the discharge begun to increase, and downstream; Figure 2), in order to obtain the contribution of the hydrostructure to the Castellano stream. The level and temperature sensor probes (TD Diver and Barologger, Eijkelkamp Soil \& Water), were placed on the stream bed within a perforated steel tube ( $2.5 \mathrm{~cm}$ internal diameter) reaching the middle of the stream to be sure that they were always submerged with water. Moreover, every 3 months from 2017 to 2019, manual flow measurements were performed using a flow meter (OTT C31, OTT Hydromet) integrating the flow velocities along the monitored stream section.

The average daily flow rates of the upstream section were subtracted from those of the downstream section to obtain the flow rate variation in the studied stretch. The obtained flow rates were further processed using the base flow index (BFI) software [31] to determine the contribution of the aquifer and to exclude the surface runoff component.

\subsection{Numerical Model Set-Up}

The translation of the conceptual model into the numerical model occurred through successive refining stages. The starting point was a simplified reconstruction of the boundary conditions and stresses, namely recharge rate and aquifer-streams interconnection. The second stage was the reconstruction of the three-dimensional distribution of $K$ values via the combined information gained by the pumping tests performed by CIIP in 2018 and analyzed with the Cooper-Jacob method (mean K value of $1.8 \times 10^{-3} \mathrm{~m} / \mathrm{s}$ ) and the geomechanical surveys (Table 1 ), which led to the realization of the steady-state model. Furthermore, some literature values were known for the above-mentioned hydrogeological units [32,33].

The domain of the model had an extension of 14,000 $\mathrm{m} \times 16,000 \mathrm{~m}$ and had been divided into 140 columns and 160 rows. The active cells area, in which groundwater flow and heads were computed, was of $47.91 \mathrm{~km}^{2}$; while the active cells volume was of $60,968 \times 10^{6} \mathrm{~m}^{3}$ with a maximum model thickness of approximately $2000 \mathrm{~m}$ and a maximum model depth of $-600 \mathrm{~m}$ ASL. The vertical discretization was completed through the subdivision into 4 layers of variable thickness, following the lithostratigraphic reconstruction (Figure 3). In Figure 3 shows the final calibrated $\mathrm{K}$ field used in both the steady state and transient model.

The top of the first layer was not horizontal, but it was mimicking the real topography, by re-interpolating a $100 \times 100 \mathrm{~m}$ resolution digital terrain model (DTM) on the MODFLOW-2005 grid. Where possible, the distance between the calculation node of the cells belonging to a given layer and the calculation nodes of the cells belonging to the adjacent layers was set not greater than $50 \%$ of the thickness of the layer, to facilitate the numerical model convergence. The base of the model domain (bottom of layer 4) was interpolated using the hydrogeological sections produced during the hydrogeological survey. 
The constant head package was used to simulate the piezometric head in the Casette Lake (Figure 2); this lake and the Castellano stream were considered the hydrogeological basin outflow, while all the model cells outside the hydrogeological basin (Figure 1) were set as no flow boundary.

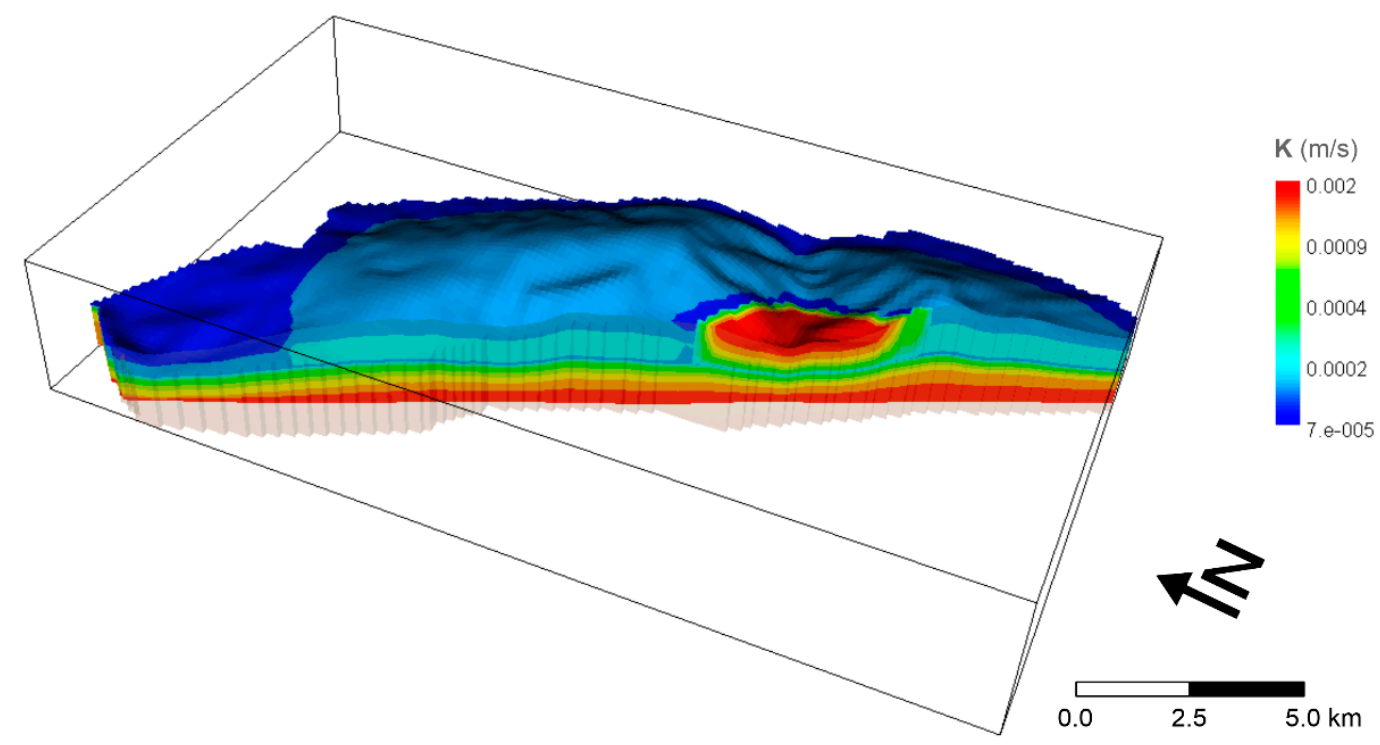

Figure 3. Three-dimensional cropped map (along the transect of Figure 1) of the hydrogeological units represented in the domain of the numerical model, vertical exaggeration 1:1.

The Castellano stream and the Salinello stream, which represent the only perennial streams in the hydrogeological basin, were simulated using the river package. The input values entered were the riverbed mean $\mathrm{K}$ value that was estimated by the Hazen formula [34] (equals to $1.0 \times 10^{-4} \mathrm{~m} / \mathrm{s}$ ) and the height of the riverbed level which was obtained from the DTM and the field survey. Clearly, the mean $\mathrm{K}$ value is an assumption that does not take into consideration the various degree of heterogeneity that are likely to be present along the stream reach [8], but this was the best estimate that was available. The river package made use of cells in which the hydrometric river stage was specified by the user (here two stages for the Castellano stream and three for the Salinello stream at monitored points); a linear interpolation was applied between the river cells with user specified values. The horizontal flow barrier (HFB) package was used to simulate the compressive faults, thus including large anisotropy in the $\mathrm{K}$ field at the basin scale.

The transient simulation was run for the period in which it was possible to continuously monitor the flow of the Castellano stream (October 2017-March 2019). The time was divided into ten stress periods to reproduce the main recharge events; the length of the periods was inferred from the peak analysis recorded in the two continuous measurement hydrometric stations along the Castellano stream. Furthermore, the average hydrometric levels of the Castellano stream in each of the ten stress periods was derived from the continuous monitoring data of the two hydrometric stations. An automated calibration process was carried out using the numerical inverse code, MODFLOW-2000 (parameter estimation and sensitivity analysis) [35]. This process was performed on the following parameters: horizontal K of the four hydrogeologic units, hydraulic conductance of riverbed and recharge. Prior information on the isotropic distribution of $\mathrm{Kx}$ and $\mathrm{Ky}$ values and on the ratio between horizontal and vertical $\mathrm{K}$ values were used in order to constrain parameters during estimation; the objective function consisted of all the available flow observations. $R^{2}$, the Nash-Sutcliffe model efficiency coefficient (NSE) and the absolute mean error (MAE) were used to infer if model calibration was satisfactory. 


\section{Results}

\subsection{Monitoring Results}

The observed inflow and outflow from the Castellano stretch that directly intercepts the Montagna dei Fiori aquifer shows a marked increment of the stream flow in this small portion of about $1 \mathrm{~km}$ length Figure 4, the increase in stream discharge due to aquifer recharge reached a maximum of about $1.2 \mathrm{~m}^{3} / \mathrm{s}$ in the first hydrological year and $0.7 \mathrm{~m}^{3} / \mathrm{s}$ in the second year. During the monitoring period, several flood events occurred, always in concomitance with the precipitation falling within the basin. In the left part of the graph in Figure 4, the increase of the stream discharge due to the aquifer recharge is particularly evident (see Castellano Downstream red line, from November 2017 to mid-April 2018).

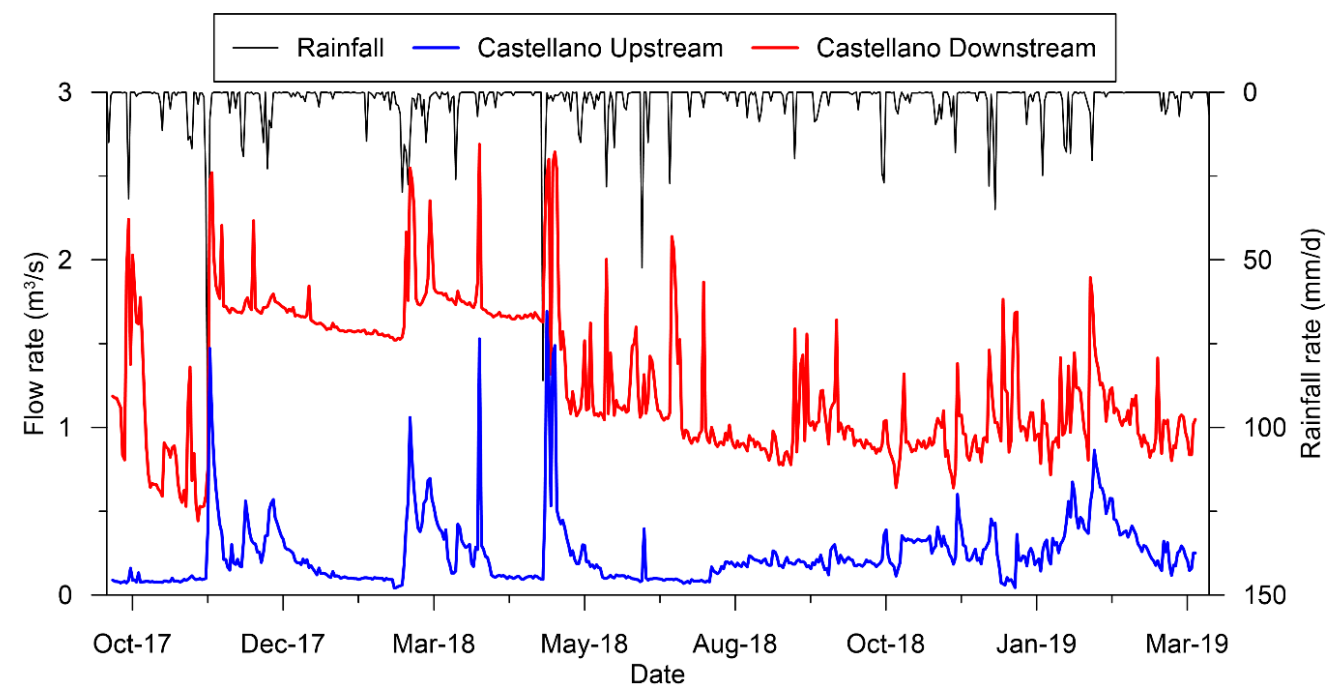

Figure 4. Continuous monitoring of the stream flow in the two instrumented sections of the Castellano stretch (upstream and downstream hydrographic stations in Figure 2 are represented with blue and red lines, respectively). Rainfall for the same period is also shown (black line).

The temperature behaviour is even more explicit than the observed stream flow, in fact while the temperature in the Castellano Upstream Station was clearly following the daily atmospheric fluctuations, the temperature in the downstream monitoring station of the Castellano stream did not vary except for four storm events when a larger component of the runoff contributed to a decrease the stream water temperature (Figure 5). This is a clear indication that the aquifer contribution in the monitored Castellano stretch is extremely significant as pointed out in other environmental settings by other studies [36,37].

Figure 6 shows the baseflow calculated via the BFI model using as input value the difference between the upstream and downstream observed flows in the Castellano stream. BFI eliminates the run-off component (flow peaks) using a simplified algorithm. This approach can be considered valid in this simple case, since the Castellano stream is the only stream reach of this area, but for complex cases like in the presence of a dense stream network or in urban environments, a distributed watershed model should be employed to accurately calculate the baseflow [38]. The baseflow feeding the Castellano stream over the monitored period is at least $400 \mathrm{l} / \mathrm{s}$ with large variations induced by rainfall events, see for example the $120 \mathrm{~mm}$ event of November 2017 that triggered a large baseflow increase. For instance, from November 2017 to mid-April 2018 around 1500 l/s were discharged by the aquifer into the Castellano stream. Accordingly, this period of high baseflow coincides with a particularly rainy meteorological period, in fact as many as $580 \mathrm{~mm}$ were recorded by the meteorological station of the Civil Protection of the Marche Region, while in the same period of the following year only $314 \mathrm{~mm}$ were recorded by the same station. 


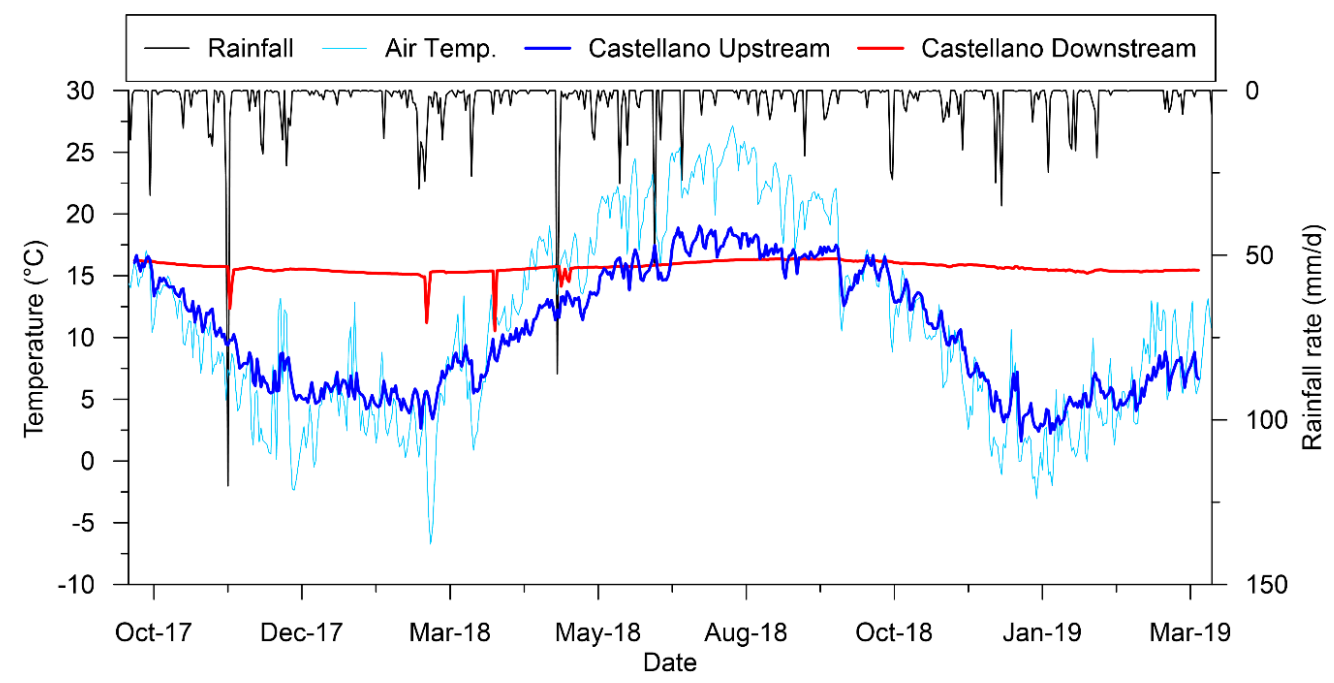

Figure 5. Continuous monitoring of the air temperature (light blue line) and of the surface water temperature in the two instrumented sections of the Castellano stretch (upstream and downstream hydrographic stations in Figure 2 are represented with blue and red lines, respectively). Rainfall for the same period is also shown (black line).

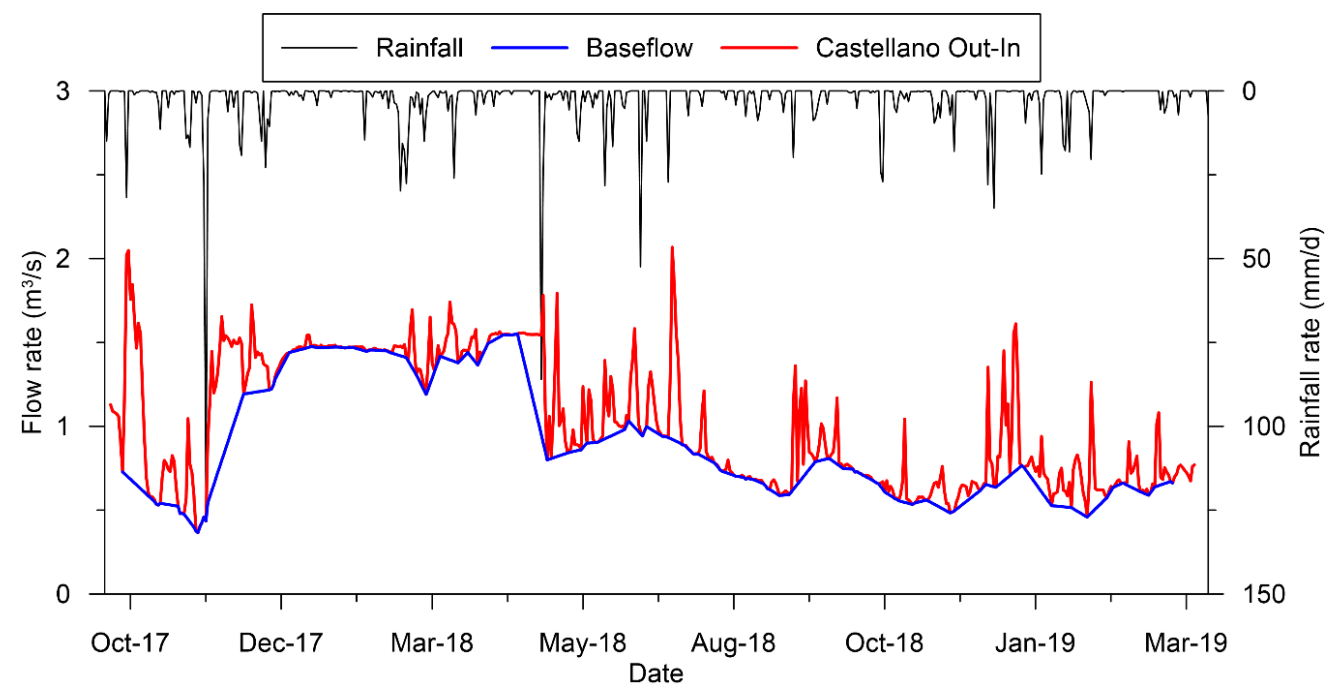

Figure 6. Flow rate difference between the two instrumented sections of the Castellano stretch (upstream and downstream hydrographic stations in Figure 2) and the calculated BFI stream baseflow. Rainfall for the same period is also shown.

\subsection{Steady State Model Results}

During the model calibration process, the initial estimates of $\mathrm{K}$ values for the different hydrogeological units were changed within the limits of physical consistency, to obtain calculated piezometric heads values (approximately $312 \mathrm{~m}$ ASL for all the wells) comparable with the ones measured (approximately 310 m ASL for all the wells) in the wells drilled by CIIP in 2018 near Casteltrosino (see Figure 2 for locations). These were the only piezometric head data available to constrain the steady state model.

The effective rainfall (recharge) was simulated with the recharge package, the estimate of the effective annual infiltration was initially set to an average value of $600 \mathrm{~mm} / \mathrm{y}(30 \%$ of precipitation), but the results showed a great discrepancy with the observed flow measurements in the Castellano stream. In fact, they were orders of magnitude higher $(8000-10,0001 / \mathrm{s})$ than those estimated by discontinuous flow rate measurements $(500-900 \mathrm{l} / \mathrm{s})$. The recharge value was then gradually reduced, reaching a mean 
value of about $378 \mathrm{~mm} / \mathrm{y}$ (19\% of precipitation). The water table in the steady state model had a variable depth with respect to the ground level, very deep near the topographic peaks and approximately above ground level near the Castellano stream (Figure 7). The aquifer was characterized by higher hydraulic gradients in the northern portion of the flow domain near to the Castellano stream and the Casette Lake. The hydraulic head gradient on average was equal to $0.5 \%$, therefore extremely low due to the elevated $\mathrm{K}$ values of the modeled hydrogeological units. The main groundwater flow direction was SSE-NNO along the ridge of the Montagna dei Fiori, locally influenced by variations in $\mathrm{K}$ and by the Salinello stream, which is located at a higher altitude than the water table, thus is only feeding and never draining the aquifer system. Furthermore, the fault system did not allow groundwater to flow through the fault planes, but instead groundwater flow was conveyed along the fault planes (Figure 7).

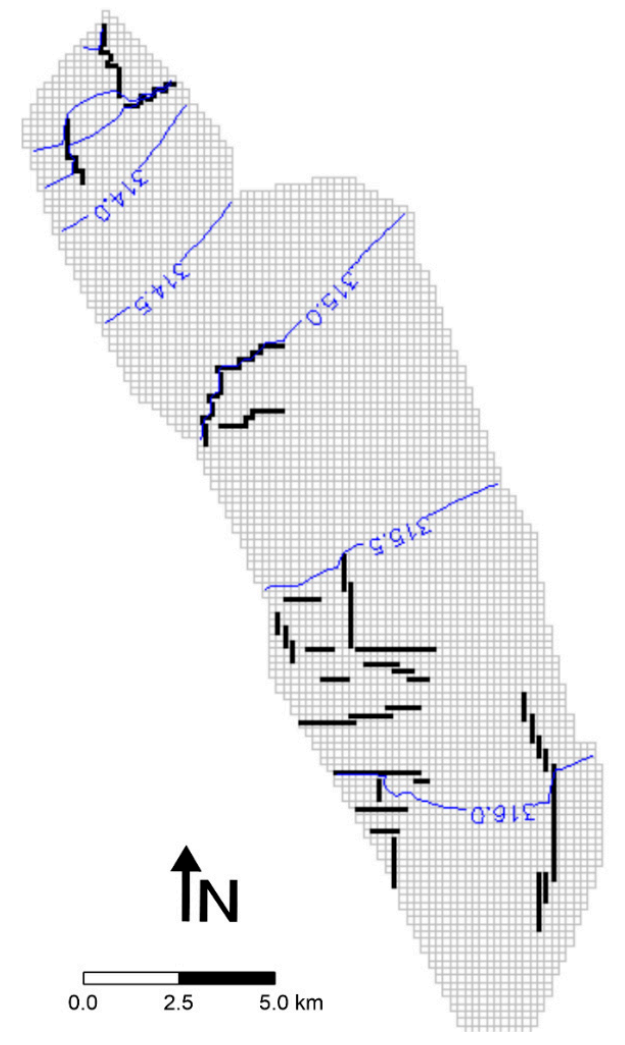

Figure 7. Output piezometric map for the steady state simulation.

The water balance is shown in Table 2. The outflow of the aquifer towards the Castellano stream is approximately $530 \mathrm{l} / \mathrm{s}$ and takes place in the central portion of the stretch here simulated, while the recharge from rivers to the aquifer is $67 \mathrm{l} / \mathrm{s}$ (calculated flow) and it is due to the Salinello stream. These data coincide with the flow measurements along the Castellano stream and the Salinello streams during the field surveys.

Table 2. Elements of the hydrogeological balance as calculated in the flow model.

\begin{tabular}{cccc}
\hline Flow Term & In $\left(\mathbf{m}^{3} / \mathbf{s}\right)$ & Out $\left(\mathbf{m}^{3} / \mathbf{s}\right)$ & In-Out $\left(\mathbf{m}^{3} / \mathbf{s}\right)$ \\
\hline Constant Head & 0.0 & 0.108 & -0.108 \\
Recharge & 0.575 & 0.0 & 0.575 \\
River & 0.067 & 0.533 & -0.466 \\
Sum & 0.642 & 0.642 & 0.0 \\
\hline Discrepancy (\%) & 0.0 & & \\
\hline
\end{tabular}


As pointed out before, the annual recharge calculated in the study area is about $19 \%$ of the average rainfall observed over the whole hydrogeological basin $(1990 \mathrm{~mm} / \mathrm{y})$ considering all the meteorological stations available, which was very similar to the mean annual precipitation for the period 1991-2020 (approximately $1800 \mathrm{~mm} / \mathrm{y}$ ) observed in this this area [32]. The estimated mean value of $380 \mathrm{~mm} / \mathrm{y}$ is consistent with the recharge values obtained in similar hydrogeological settings [33]. The mean recharge rate multiplied by the area of the active cells in the numerical model is equal to an inflow of about 575 1/s (Table 2).

Considering all the components of the water balance, the inflows and outflows in the study area are around $640 \mathrm{l} / \mathrm{s}$, a result that is consistent with the water balances drawn up with simplified balance equations in similar settings [33,35].

Unfortunately, since the system is very complex from a structural point of view, with faulted hydrogeological units and boundaries that cannot be easily reconstructed in depth, it is difficult to assign consistent limits of reliability to the simulation without observed head data to calibrate the model. Thus, a transient flow model was built up and calibrated versus observed flows as reported in the next section.

\subsection{Transient State Model Results}

The results of the transient simulation highlighted that the piezometric fluctuations induced by the different recharge rates applied during the different stress periods provoked changes in the Castellano stream baseflow. A piezometric peak was reproduced in January 2018, while the minimum occurred in February 2019 (piezometric maps not shown). However, the general trend of the piezometric heads remains, which moves sub-parallel to the main fracturing direction along the ridge of the Montagna dei Fiori, and by then it realigns along the direction of the Castellano valley.

The calibration of the model has reached a good degree of accuracy concerning the calculation of the flow rates towards the Castellano stream, which fluctuate mimicking those recorded by the continuous monitoring stations, as shown in Figure 8. Moreover, also the scatter diagram for the direct comparison between the observed and the calculated flow rates, gives acceptable $\mathrm{R}^{2}(0.75)$, NSE (0.53) and $\operatorname{AME}\left(0.146 \mathrm{~m}^{3} / \mathrm{s}\right)$, even if the model tends to overestimate the flow rates entering the Castellano stream during the high discharge periods. This is likely due to the fact that the simulated medium is fractured, while the model corresponds to an equivalent porous medium.
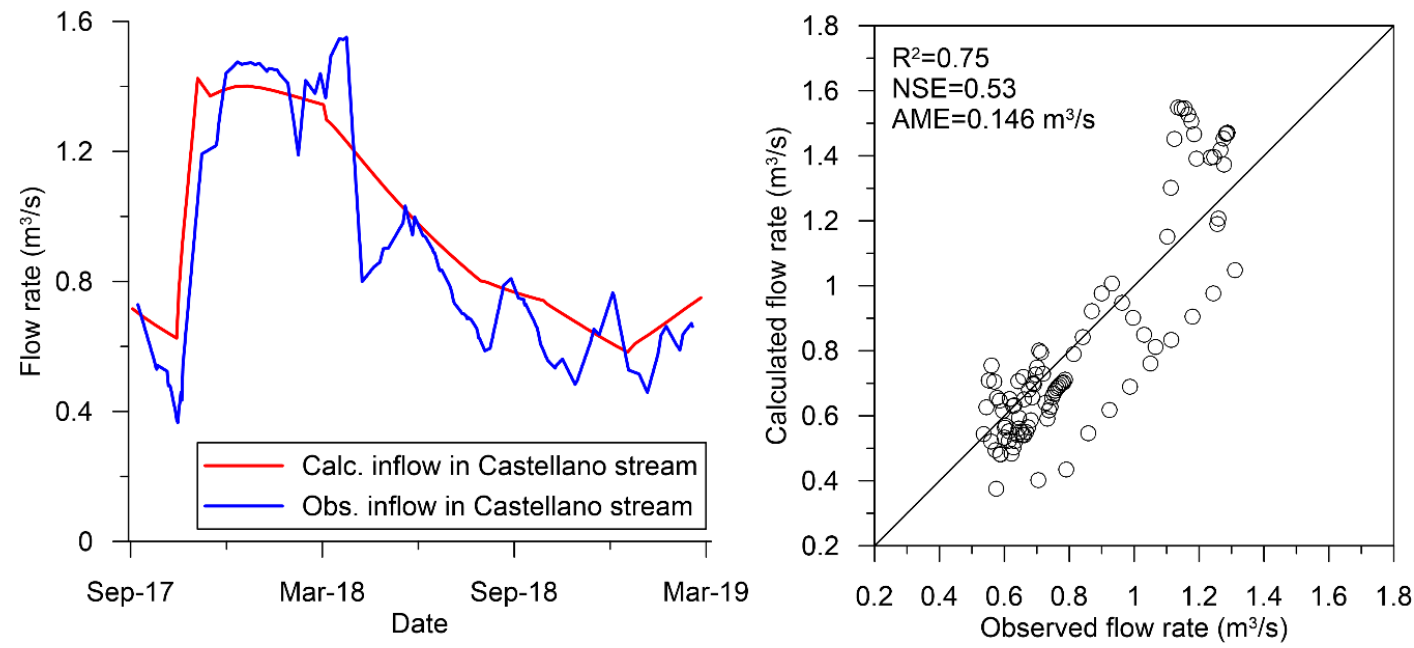

Figure 8. Calculated and observed inflow from the aquifer towards the Castellano stretch, as time series (left panel) and scatter diagram (right panel). 


\subsection{Sensitivity Analysis Results}

After conducting the model sensitivity analysis to the perturbation of the input parameters with MODFLOW-2000, it was clear that the most influencing parameters were the recharge values and the conductance value of the Castellano stream (Table 3). Given that the shape and geometry of the Castellano stream are known, this means that the $\mathrm{K}$ of the riverbed is the most influencing parameter after the recharge values in stress periods 2 and 3 . The model sensitivity to the perturbation of the $\mathrm{K}$ values for the layers 1 and 2 is less pronounced and decreases further when $K$ values set with the HFB package are also perturbed. This means that the geomechanical and hydrogeological characterizations were of sufficient quality to allow a unique $\mathrm{K}$ field reconstruction. The high recharge and river conductance sensitivities are not surprising, since these parameters drive the groundwater/surface water interactions in this numerical model; besides, they tend to be the most uncertain parameters in large scale models $[39,40]$. The final riverbed $\mathrm{K}$ value was $1.7 \times 10^{-4} \mathrm{~m} / \mathrm{s}$, which was similar to the initial estimate.

Table 3. Results of the sensitivity analysis with MODFLOW-2000.

\begin{tabular}{ccc}
\hline Parameter & Optimized Values & Composite Scaled Sensitivity \\
\hline Recharge in stress period 2 & $518 \mathrm{~mm} / \mathrm{y}$ & 0.392 \\
Recharge in stress period 3 & $259 \mathrm{~mm} / \mathrm{y}$ & 0.204 \\
Recharge in stress period 7 & $52 \mathrm{~mm} / \mathrm{y}$ & 0.039 \\
Recharge in stress period 10 & $181 \mathrm{~mm} / \mathrm{y}$ & 0.030 \\
K layer 1 & $1.1 \times 10^{-4} \mathrm{~m} / \mathrm{s}$ & 0.049 \\
K layer 2 & $2.2 \times 10^{-4} \mathrm{~m} / \mathrm{s}$ & 0.057 \\
Castellano river conductance & $1.9 \times 10^{-2} \mathrm{~m}^{2} / \mathrm{s}$ & 0.133 \\
HFB K & $1.0 \times 10^{-9} \mathrm{~m} / \mathrm{s}$ & $1.0 \times 10^{-4}$ \\
\hline
\end{tabular}

\section{Conclusions}

The continuous monitoring of the Castellano stream provided insight into the relationships between surface waters and the fractured aquifer. In particular, the temperature monitoring provided an independent information on the contribution of groundwater discharge to the Castellano stream. However, it must be stressed that the temperature information only provided additional qualitative information on the considerable contribution of groundwater to streamflow but was not considered for the baseflow analysis and neither used for further flux quantifications in this study. The transient flow model was able to reproduce the stream baseflow reasonably well. Nevertheless, sub-reach interactions could not be assessed with the available dataset; in fact, only interactions due to large-scale water level differences between aquifer and stream were taken into account but not the processes occurring due to local flow processes along the streambed. The automated sensitivity analysis, performed with MODFLOW-2000, showed that recharge was the most uncertain parameter, followed by hydraulic conductivity zonation and river conductance. Thus, these parameters should be better investigated in future studies in similar mountain regions where groundwater monitoring networks are usually lacking. Nevertheless, the presented monitoring and modelling approach could be employed to quantify the groundwater/surface water interactions in analogous hydrogeological settings.

Author Contributions: Conceptualization, A.T., T.N., S.P., N.C. and M.M.; methodology, A.T., N.C.; software, N.C.; validation, M.M..; formal analysis, N.C., A.T. and S.P.; investigation, A.T., S.P.; resources, T.N.; data curation, A.T., N.C.; writing-original draft preparation, N.C., A.T.; writing-review and editing, M.M., A.T.; visualization, N.C., A.T.; supervision, T.N.; project administration, T.N.; funding acquisition, T.N. All authors have read and agreed to the published version of the manuscript.

Funding: This research was funded by CIIP spa-Cicli Integrati Impianti Primari under the "Research project on the groundwater circulation and recharge processes in the Montagna dei Fiori basin".

Acknowledgments: The authors would like to thank the four anonymous reviewers for their precious comments and positive criticisms that led to substantially improving the original manuscript. 
Conflicts of Interest: The authors declare no conflict of interest. The funders had no role in the design of the study; in the collection, analyses or interpretation of data; in the writing of the manuscript, or in the decision to publish the results.

\section{References}

1. Kaandorp, V.P.; Molina-Navarro, E.; Andersen, H.E.; Bloomfield, J.P.; Kuijper, M.J.; de Louw, P.G. A conceptual model for the analysis of multi-stressors in linked groundwater-surface water systems. Sci. Total. Environ. 2018, 627, 880-895. [CrossRef] [PubMed]

2. Essaid, H.I.; Zamora, C.M.; McCarthy, K.A.; Vogel, J.R.; Wilson, J.T. Using heat to characterize streambed water flux variability in four stream reaches. J. Environ. Qual. 2008, 37, 1010-1023. [CrossRef] [PubMed]

3. Schmidt, C.; Bayer-Raich, M.; Schirmer, M. Characterization of spatial heterogeneity of groundwater-stream water interactions using multiple depth streambed temperature measurements at the reach scale. Hydrol. Earth Sys. Sci. 2006, 10, 849-859. [CrossRef]

4. Conant, B., Jr. Delineating and quantifying ground water discharge zones using streambed temperatures. Ground Water 2004, 42, 243-257. [CrossRef]

5. Anibas, C.; Schneidewind, U.; Vandersteen, G.; Joris, I.; Seuntjens, P.; Batelaan, O. From streambed temperature measurements to spatial-temporal flux quantification: Using the LPML method to study groundwater-surface water interaction. Hydrol. Process. 2016, 30, 203-216. [CrossRef]

6. Kazakis, N.; Oikonomidis, D.; Voudouris, K.S. Groundwater vulnerability and pollution risk assessment with disparate models in karstic, porous, and fissured rock aquifers using remote sensing techniques and GIS in Anthemountas basin, Greece. Environ. Earth Sci. 2015, 74, 6199-6209. [CrossRef]

7. Fleckenstein, J.H.; Krause, S.; Hannah, D.M.; Boano, F. Groundwater-surface water interactions: New methods and models to improve understanding of processes and dynamics. Adv. Water Resour. 2010, 33, 1291-1295. [CrossRef]

8. Schornberg, C.; Schmidt, C.; Kalbus, E.; Fleckenstein, J.H. Simulating the effects of geologic heterogeneity and transient boundary conditions on streambed temperatures-Implications for temperature-based water flux calculations. Adv. Water Resour. 2010, 33, 1309-1319. [CrossRef]

9. Briggs, M.A.; Buckley, S.F.; Bagtzoglou, A.C.; Werkema, D.D.; Lane, J.W., Jr. Actively heated high-resolution fiber-optic-distributed temperature sensing to quantify streambed flow dynamics in zones of strong groundwater upwelling. Water Resour. Res. 2016, 52, 5179-5194. [CrossRef]

10. Berkowitz, B. Characterizing flow and transport in fractured geological media: A review. Adv. Water Resour. 2002, 25, 861-884. [CrossRef]

11. Zhang, Y.-K.; Bai, E.-W.; Libra, R.; Rowden, R.; Liu, H. Simulation of spring discharge from a limestone aquifer in Iowa. Hydrogeol. J. 1996, 4, 41-54. [CrossRef]

12. Granata, F.; Saroli, M.; de Marinis, G.; Gargano, R. Machine learning models for spring discharge forecasting. Geofluids 2018, 8328167. [CrossRef]

13. Scanlon, B.R.; Mace, R.E.; Barrett, M.E.; Smith, B. Can we simulate regional groundwater flow in a karst system using equivalent porous media models? Case study, Barton Springs Edwards aquifer, USA. J. Hydrol. 2003, 276, 137-158. [CrossRef]

14. Martínez-Santos, P.; Andreu, J.M. Lumped and distributed approaches to model natural recharge in semiarid karst aquifers. J. Hydrol. 2010, 388, 389-398. [CrossRef]

15. Panagopoulos, G. Application of MODFLOW for simulating groundwater flow in the Trifilia karst aquifer, Greece. Environ. Earth Sci. 2012, 67, 1877. [CrossRef]

16. Sanford, W. Recharge and groundwater models: An overview. Hydrogeol. J. 2002, 10, 110-120. [CrossRef]

17. Fleury, P.; Plagnes, V.; Bakalowicz, M. Modelling of the functioning of karst aquifers with a reservoir model: Application to Fontaine de Vaucluse (South of France). J. Hydrol. 2007, 345, 38-49. [CrossRef]

18. Sun, W.; Wu, Q.; Liu, H.; Jiao, J. Prediction and assessment of the disturbances of the coal mining in Kailuan to karst groundwater system. Phys. Chem. Earth. 2015, 89, 136-144. [CrossRef]

19. Xue, S.; Liu, Y.; Liu, S.; Li, W.; Wu, Y.; Pei, Y. Numerical simulation for groundwater distribution after mining in Zhuanlongwan mining area based on visual MODFLOW. Environ. Earth Sci. 2018, 77, 400. [CrossRef]

20. Fernández-Álvarez, J.P.; Álvarez-Álvarez, L.; Díaz-Noriega, R. Groundwater numerical simulation in an open pit mine in a limestone formation using MODFLOW. Mine Water Environ. 2016, 35, 145-155. [CrossRef] 
21. Ragab, R.; Bromley, J.; Dörflinger, G.; Katsikides, S. IHMS—Integrated Hydrological Modelling System. Part 2. Application of linked unsaturated, DiCaSM and saturated zone, MODFLOW models on Kouris and Akrotiri catchments in Cyprus. Hydrol. Process. 2010, 24, 2681-2692. [CrossRef]

22. Shoemaker, W.B.; Cunningham, K.J.; Kuniansky, E.L.; Dixon, J. Effects of turbulence on hydraulic heads and parameter sensitivities in preferential groundwater flow layers. Water Resour. Res. 2008, 44, W03501. [CrossRef]

23. Surinaidu, L.; Bacon, C.G.D.; Pavelic, P. Agricultural groundwater management in the Upper Bhima Basin, India: Current status and future scenarios. Hydrol. Earth Sys. Sci. 2013, 17, 507-517. [CrossRef]

24. Guthke, A. Defensible Model Complexity: A Call for Data-Based and Goal-Oriented Model Choice. Ground Water 2017, 55, 646-650. [CrossRef] [PubMed]

25. Harbaugh, A.W. MODFLOW-2005, the US Geological Survey modular ground-water model: The ground-water flow process. U.S. Geological Survey Techniques and Methods 6-A16; US Department of the Interior, US Geological Survey: Reston, VA, USA, 2005; 253p.

26. Chiang, W.H. Processing Modflow: An Integrated Modeling Environment for the Simulation of Groundwater Flow, Transport and Reactive Processes; Simcore Software: Irvine, CA, USA, 2012; 484p.

27. Snow, D.T. Anistotropic permeability of fractured media. Water Resour. Res. 1969, 5-6, 1273-1289. [CrossRef]

28. Mechal, A.; Birk, S.; Dietzel, M.; Leis, A.; Winkler, G.; Mogessie, A.; Kebede, S. Groundwater flow dynamics in the complex aquifer system of Gidabo River Basin (Ethiopian Rift): A multi-proxy approach. Hydrogeol. J. 2017, 25, 519-538. [CrossRef]

29. Boni, C.F.; Mastrorillo, L.; Petitta, M. Scomposizione della portata dei corsi d'acqua dell'Appennino Marchigiano con il metodo delle portate mensili caratteristiche. Geol. Appl. Idrogeol. 1993, 28, 121-129.

30. Mastrorillo, L.; Petitta, M. Effective infiltration variability in the Umbria-Marche carbonate aquifers of central Italy. J. Mediter. Earth Sci. 2010, 2, 9-18. [CrossRef]

31. Morawietz, M.; (University of Oslo, Oslo, Norway). Personal communication, 1997.

32. Gentilucci, M.; Barbieri, M.; Lee, H.S.; Zardi, D. Analysis of Rainfall Trends and Extreme Precipitation in the Middle Adriatic Side, Marche Region (Central Italy). Water 2019, 11, 1948. [CrossRef]

33. Nanni, T.; Vivalda, P. The aquifers of the Umbria-Marche Adriatic region: Relationships between structural setting and groundwater chemistry. Boll. Soc. Geol. Ital. 2005, 124, 523-542.

34. Hazen, A. Some physical properties of sands and gravels. Mass. State Board Health Ann. Rept. 1892, 539-556.

35. Mussi, M.; Nanni, T.; Tazioli, A.; Vivalda, P.M. The Mt Conero limestone ridge: The contribution of stable isotopes to the identification of the recharge area of aquifers. Ital. J. Geosci. 2017, 136, 186-197. [CrossRef]

36. Hill, M.C.; Banta, E.R.; Harbaugh, A.W.; Anderman, E.R. MODFLOW-2000, the US Geological Survey Modular Ground-Water Model; User Guide to the Observation, Sensitivity, and Parameter-Estimation Processes and Three Post-Processing Programs No. 2000-184; US Geological Survey: Reston, VA, USA, 2000.

37. Krause, S.; Blume, T. Impact of seasonal variability and monitoring mode on the adequacy of fiber-optic distributed temperature sensing at aquifer-river interfaces. Water Resour. Res. 2013, 49, 2408-2423. [CrossRef]

38. Loheide, S.P.; Gorelick, S.M. Quantifying stream-Aquifer interactions through the analysis of remotely sensed thermographic profiles and in situ temperature histories. Environ. Sci. Technol. 2006, 40, 3336-3341. [CrossRef] [PubMed]

39. Partington, D.; Brunner, P.; Simmons, C.T.; Werner, A.D.; Therrien, R.; Maier, H.R.; Dandy, G.C. Evaluation of outputs from automated baseflow separation methods against simulated baseflow from a physically based, surface water-groundwater flow model. J. Hydrol. 2012, 458, 28-39. [CrossRef]

40. Sophocleous, M.; Perkins, S.P. Calibrated models as management tools for stream-aquifer systems: The case of central Kansas, USA. J. Hydrol. 1993, 152, 31-56. [CrossRef]

(C) 2020 by the authors. Licensee MDPI, Basel, Switzerland. This article is an open access article distributed under the terms and conditions of the Creative Commons Attribution (CC BY) license (http://creativecommons.org/licenses/by/4.0/). 